\title{
Changes in Epipelic Diatom Diversity from the Savannah River Estuary
}

\author{
Kalina M. Manoylov, Joseph N. Dominy Jr.
}

Department of Biological and Environmental Sciences, Georgia College and State University, Milledgeville, USA.

Email: kalina.manoylov@gcsu.edu

Received December $12^{\text {th }}, 2012$; revised December $31^{\text {st }}, 2012$; accepted January $23^{\text {rd }}, 2013$

\begin{abstract}
Littoral zones can be characterized with temporal exposure of algae to diurnal desiccation at low tides. Combinations of diverse freshwater, marine, and brackish diatoms dominate exposed mud samples. With enlargement of the delta of the Savannah River, Georgia and other anthropogenic influences, changes in the rich epipelic community will not be estimated accurately without baseline data. In the current study, mud samples were taken from the Savannah River estuary along with physicochemical characteristics every two months throughout 2011. Live algal communities were assessed in every sample and live to dead diatom proportions in the communities were calculated. Cleaned diatoms were analyzed following standard protocols. Community indices were compared between sampling events and with literature reports from similar habitats in the Southeastern USA diverse diatom community of 241 species was documented and 39 of those species should be described as new to science. Decrease in species richness and diversity was due to dominance of representatives of the genera Cymatosira and Minidiscus during the summer months.
\end{abstract}

Keywords: Epipelic Diatoms; Brackish Water; Savannah River

\section{Introduction}

Widening and deepening of river deltas, as proposed for the Savannah River with the Savannah Harbor Expansion Project [1] can cause changes in tidal height, influx of salt water and sedimentation. The Savannah River covers a total of 27,194 square $\mathrm{km}$ and stretches $504 \mathrm{~km}$ across the Piedmont and Upper coastal plain until it then empties into the Atlantic Ocean, which is about $21 \mathrm{~km}$ from the city of Savannah, and $31 \mathrm{~km}$ from the site location. The river provides water to two major metropolitan areas in Georgia including Savannah and Augusta and is the nation's 10th largest port for container ships. The Savannah River has cultural and historic value in Georgia. It is also well known for its scenic beauty and natural diversity, but the ecological health of the river is declining, due to the estuary being heavily contaminated by sewage and industrial wastes [2].

Algal communities within estuaries consist of a mixed flora containing freshwater, brackish, and marine species that can be potentially influenced by change in water quantity and chemical composition. Mud samples found within littoral zones contain both epipelic and epipsammic diatom dominated communities [3]. Epipelic diatoms are the primary inhabitants of mud samples and are found within a thin horizontal and time dependent region (surfacing during favorable conditions) at the sediment- water interface. Light penetration throughout the sediment is around $2-3 \mathrm{~mm} \mathrm{[4]} \mathrm{and} \mathrm{the} \mathrm{variability} \mathrm{of} \mathrm{pH}, \mathrm{O}_{2}$, and nutrients can range exponentially within only a few millimeters of depth [5].

Few studies have been dedicated to the littoral zones found throughout brackish waters in the Southeastern United States. In 1956 Friedrich Hustedt examined two mud samples that were taken from Beaufort, North Carolina [6]. In his study he reported a total of 369 species of diatoms $(99 \%$ of which were salt water species), and $25 \%$ of the reported were new to science. To this day Hustedt's study is the most comprehensive report on epipelic diatoms from the southeastern US, but does not address changes in abundance through time. Recently the USGS NAWQA has also been collecting algal samples found in rivers, lakes, and wetlands throughout the Southeast, with some overlap with our sites [7]. Algal communities from the Carolina bays and other wetland regions along the Atlantic coastal plain in South Carolina, were dominated by freshwater diatoms [8]. Centric diatoms from the coastal waters of Florida and Georgia have been monitored for about 20 years and dominated by Thalassiosira and Cyclotella [9]. Other regional studies within the upper most protected regions of the Savannah River [10] documented great biodiversity of freshwater habitats with many new species docu- 
mented. Marine taxa such as Cymatosira belgica, Paralia sulcata, and Delphineis surirella were documented to occur continuously in all depths ranging from surface samples to $95 \mathrm{~cm}$, dating back to the Holocene period from varying depths within the intertidal salt water marshes, located in St. Catherine's Island, Georgia [11].

The objectives of this study were to: identify algal communities present within mud samples taken during low tide periods, and create a baseline information for comparison and evaluation of magnitude effect with future changes within the epipelic community. Second, calculate community indices and infer changes in biodiversity through seasons. Lastly to compare epipelic communities found 50 years ago by Hustedt with the current study [6].

\section{Material and Methods}

\subsection{Sample Collection}

Mud samples were taken from the Savannah River estuary through 2011, with an attempt to follow significant changes in temperature through the seasons (Savannah River USGS site 2198920, location Lat 3209'57" Long $\left.81^{\circ} 09^{\prime} 14^{\prime \prime}\right)$. Sampling events took place during the months of January, March, June, October, and December 2011. All sample collections followed standard protocols for sampling methods and processing [12]. Mud samples were taken each time during low tide events. Composite samples were taken by scraping the top $1 \mathrm{~mm}$ surface layer of the sediment in triplicate for random and comprehensive representation.

\subsection{Physicochemical Characteristics}

Physicochemical measurements: temperature, $\mathrm{pH}$, conductivity, turbidity, and dissolved oxygen content were measured during each event for both the seasonal and observational study, using a YSI 556 Multiprobe System (YSI Inc., Yellow Springs, Ohio) at the time of collection. In addition, chemical data was obtained from the USGS website so that long term monitoring analyses gathered within the field could be verified with a second set of readings. Nutrient data such as $\mathrm{N}$ and $\mathrm{P}$ concentrations were also obtained from the USGS site

(http://waterdata.usgs.gov/nwis). All samples were preserved within an hour of collection with formaldehyde (3\% final concentration).

\subsection{Diatom Assessment}

Enumeration followed standard methods [13] by assessing whole communities using a Palmer Maloney counting chamber at $400 \times$ magnification [14] and scanning a flat slide for evidence of chloroplasts present. At least 100 natural algal units were enumerated for each sample to determine the dominant algal group. Diatoms were processed following standard methods [15]. Processed subsamples were mounted on microscope slides with Naphrax $^{\circledR}$ (Brunel Microscopes Ltd., Chippenham, Wiltshire, UK) mounting medium to make permanent slides. For diatom counts a minimum of 400 valves were counted at $1000 \times$ magnification. Taxa were identified to the lowest taxonomic level. Additionally each slide was scanned until no new taxa were observed for total species richness. Relative abundances were reported from diatom analysis. Identification of taxonomy was based on [1621]. Permanent slides were archived and deposited as part of the diatom slide collection of the GCSU Natural History Museum.

For SEM studies, aliquots of processed material were air dried onto $15 \mathrm{~cm}^{2}$ pieces of aluminum foil. The foil was trimmed into smaller pieces and mounted on aluminum stubs with double-sided tape. The stubs were then coated with gold-palladium using a Polaron Sputter Coater for ca. $1.5 \mathrm{~min}$ at $1.8 \mathrm{kV}$. A Leo-Zeiss 982-DSM electron microscope was used for SEM analysis. Digital images were captured and plates were assembled using Adobe Photoshop CS4. Morphological terminology follows [22,23].

\subsection{Indices Calculated}

All community attributes were calculated based upon valve counts as well as species abundance. Dominant taxa with relative abundance of $5 \%$ or more in at least 1 sample. Species within the list were then designated as freshwater if the taxon appeared in the North American Water Quality Assessment most current list maintained by the Academy of Natural sciences of Philadelphia for the last 20 years in both rivers and lakes. All the other taxa were then classified as marine unless the original description designated it as being brackish.

Standard community indices including species richness (SR), species evenness (J', [24]), and species diversity were calculated for all samples. (H', [25]). Maximum biodiversity (Hmax) was calculated as the natural logarithm of the documented total species richness number $(\mathrm{Hmax}=\ln (\mathrm{SR}))$. Species evenness was calculated as a proportion of the Shannon diversity and maximum biodiversity documented $\mathrm{J}^{\prime}=\mathrm{H}^{\prime} / \mathrm{Hmax}$. The Sorensen Similarity Index [26] compared the number of common species between sample combinations, it takes under consideration presence/absence of species and is not biased by small sample size or relative proportions.

\section{Results}

\subsection{Physicochemical Characteristics}

Temperature for the year followed seasonal changes. The average air temperature for the sample site was $22.8^{\circ} \mathrm{C}$ 
ranging from $8.2^{\circ} \mathrm{C}$ to $35.9^{\circ} \mathrm{C}$. Average water temperature was $18.9^{\circ} \mathrm{C}$ and ranged from $8.7^{\circ} \mathrm{C}$ to $29.3^{\circ} \mathrm{C}$. Dissolved oxygen had an average value of $6.8 \mathrm{mg} / \mathrm{L}$, with a range of $4.5 \mathrm{mg} / \mathrm{L}$ to $9.7 \mathrm{mg} / \mathrm{L}$. The average $\mathrm{pH}$ was 7.5 and remained neutral throughout the year. Turbidity was 49.6 NTU on average and ranged from 26 NTU to 90 NTU. Average conductivity throughout the year was $11,294 \mu \mathrm{S} / \mathrm{cm}$ and had a range of $4570 \mu \mathrm{S} / \mathrm{cm}$ to 17,400 $\mu \mathrm{S} / \mathrm{cm}$. Nutrient concentrations throughout the year were $0.46 \mathrm{mg}$ to $1.6 \mathrm{mg}$ of total nitrogen $/ \mathrm{L}$ with an average concentration of $0.92 \mathrm{mg}$ of TN/L. Total phosphate was $0.14 \mathrm{mg}$ to $0.49 \mathrm{mg}$ of TP/L with an average $0.24 \mathrm{mg}$ of TP/L.

\subsection{Algal Community Assessment}

A total of 241 diatoms were documented during this study, 203 of those taxa were identified to the species level. The remaining $16 \%$ of all documented taxa were identified as unknown or c.f. based on size not conforming to available literature or potentially as new to science. Ten taxa were observed as dominant species (Table 1).

Centric diatoms like Minidiscus sp.1 (Figure 1(3); Figures 4(1) and (2)), Paralia sulcata (Figures 1(4) and (11)), Cyclotella atomus (Figure 2(12)) and Thalassiosira sp.1 (Figure 1(15)) were documented as abundant throughout the year (Table 1). Other centric diatoms like Coscinodiscus denarius (Figure 1(1)), Puncticulata cf. radiosa (Figure 1(2)), Actinoptychus cf. serianus var. minor (Figure 1(5)), Discostella stelligera (Figure 1(6)), Thalassiosira oestrupii var. venrickae (Figures 1(7) and (8)), Actinoptychus serianus (Figure 1(9)), Cyclotella sp.1 (Figure 1(12)), cf. Ditylum sp.1 (Figure 1(13)) and Cyclotella littoralis (Figure 1(14)) were rare but per-

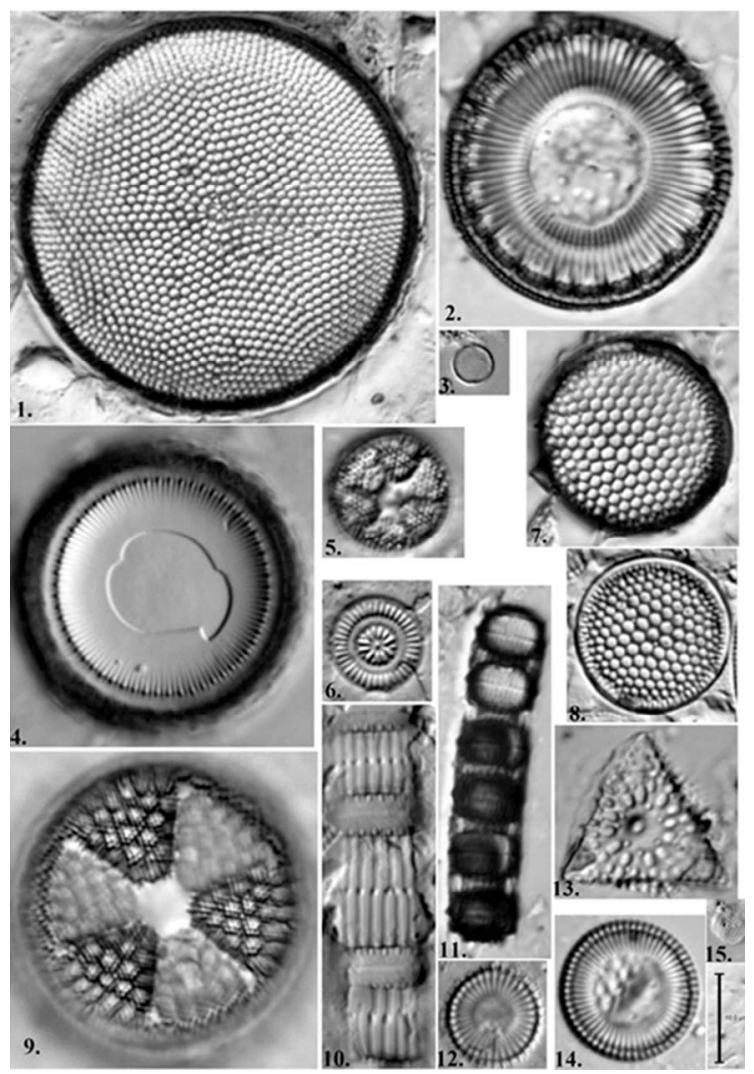

Figure 1. (1)-(15) Diatoms from the Savannah River mud samples (Light micrographs). (1) Coscinodiscus denarius Schmidt; (2) Puncticulata cf. radiosa (Grunow) Håkansson; (3) Counted as Minidiscus sp.1; (4), (11) Paralia sulcata (Ehrenberg) Cleve; (5) Actinoptychus cf. serianus var. minor Cleve-Euler; (6) Discostella stelligera (Hustedt) Houk et Klee; (7), (8) Thalassiosira oestrupii var. venrickae Fryxell et Hasle; (9) Actinoptychus serianus Ehrenberg; (10) Skeletonema costatum (Greville) Cleve; (12) Cyclotella sp.1; (13) cf. Ditylum sp.1 valve view; (14) Cyclotella littoralis Lange et Sybertsen; (15) Thalassiosira sp.1. Scale bar $10 \mu \mathrm{m}$.

Table 1. Relative abundance of dominant taxa Savannah River USGC long-term site 2198920 , abundances given if $>10 \%$, $x x$ $=5 \%-9 \%$, and $x \leq 5 \%$.

\begin{tabular}{|c|c|c|c|c|c|}
\hline Taxon & January & March & June & October & December \\
\hline Cymatosirabelgica & 29 & 21 & 51 & 40 & 37 \\
\hline Minidiscus sp. 1 & $\mathrm{xx}$ & & 27 & $\mathrm{xx}$ & $\mathrm{xx}$ \\
\hline Paraliasulcata & $\mathrm{xx}$ & $\mathrm{x}$ & & $\mathrm{x}$ & $\mathrm{x}$ \\
\hline Naviculasalinarum & 12 & & & & \\
\hline Nitzschiabrevissima & 13 & & & & \\
\hline Cylindrothecagracilis & $\mathrm{xx}$ & 15 & & & $\mathrm{x}$ \\
\hline Cyclotellaatomus & $\mathrm{xx}$ & 22 & $\mathrm{xx}$ & $\mathrm{x}$ & $\mathrm{x}$ \\
\hline Nitzschialaevis & & $\mathrm{xx}$ & & $\mathrm{x}$ & $\mathrm{x}$ \\
\hline Naviculaerifuga & $\mathrm{x}$ & $\mathrm{xx}$ & & & $\mathrm{x}$ \\
\hline Thalassiosira sp.1 & & & $\mathrm{x}$ & $\mathrm{xx}$ & $\mathrm{xx}$ \\
\hline
\end{tabular}




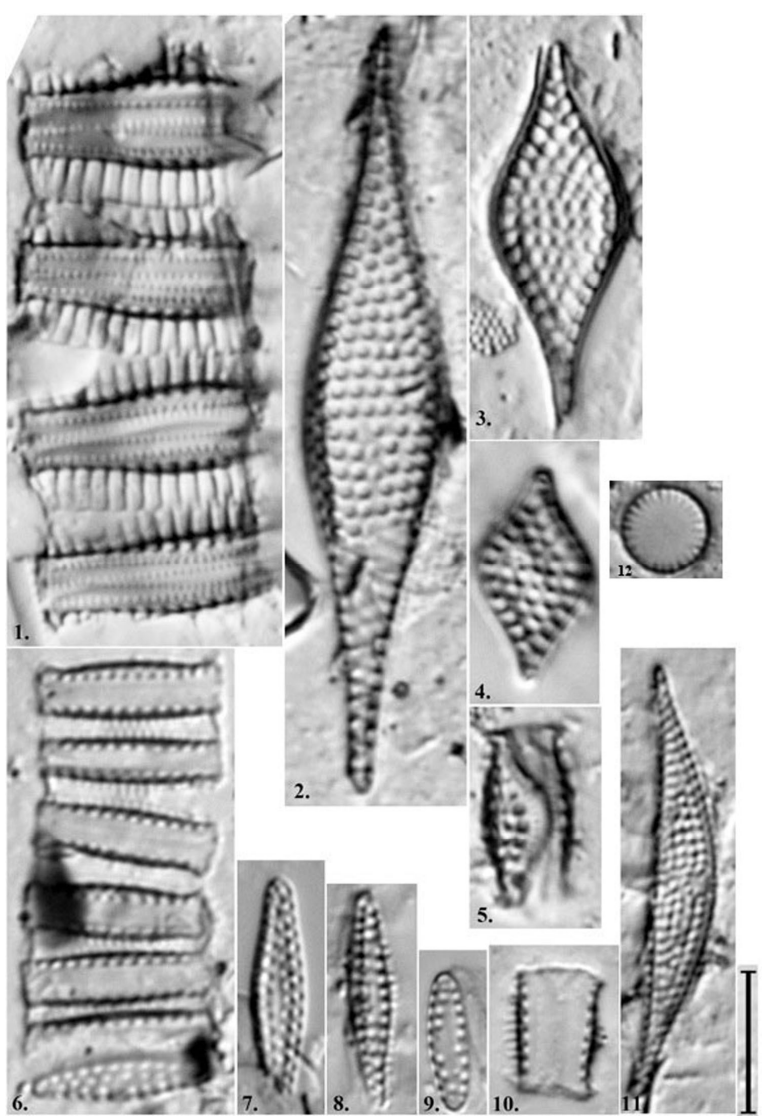

Figure 2. (1)-(12) Diatoms from the Savannah River mud samples (Light micrographs). (1)-(5) Cymatosira lorenziana Grunow; (6)-(10) Cymatosira belgica Grunow; (11) Campylosira cymbelliformis (Schmidt) Grunow in Van Heurck; (12) Cyclotella atomus Hustedt. Scale bar $10 \mu \mathrm{m}$.

sistent. There was an increase in the overall abundances of chain forming centrics like Skeletonema costatum (Figure 1(10); Figure 4(3)) and Paralia sulcata (Figures 1(4) and (11)). Small centric diatoms like Minidiscus chilensis (Figure 4(1)), Minidiscus trioculatus (Figure 4(2)), and Thalassiosira decipiens (Figure 4(4)) were identified to species only after SEM analyses.

An araphid pennate diatom Cymatosira belgica (Figures 2(6)-(10); Figure 4(5)) was identified as the dominant algal species, average to occur $35 \%$, ranging from $21 \%$ during March to $51 \%$ in June (Table 1). Other chain forming araphid diatoms like Cymatosira lorenziana (Figures 2(1)-(5); Figure 4(6)) and Campylosira cymbelliformis (Figure 2(11)) were rare and persistent in all samples.

The highest numbers of other pennate diatoms able to move up and down the mud layers, Cylindrotheca gracilis (Figure 3(1)), Navicula erifuga (Figure 3(8)), Nitzschia brevissima (Figure 3(12); Figures 4(7) and (8)), Geissleria decussis (Figure 3(15)) and Navicula salina rum (Figure 4(10)) were found during January (Table 1). Araphid diatoms like Thalassionema nitzschioides (Fig-

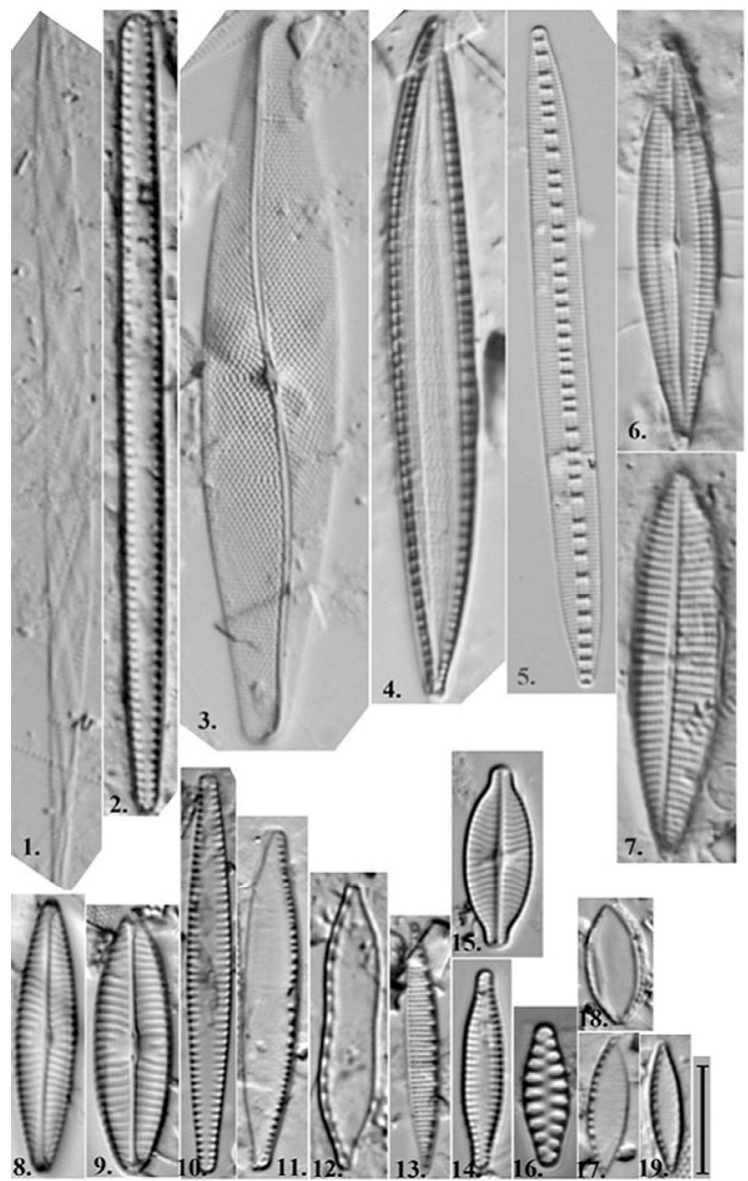

Figure 3. (1)-(19) Diatoms from the Savannah River mud samples (Light micrographs). (1) Cylindrotheca gracilis (Brébisson in Kützing) Grunow in Van Heurck; (2) Thalassionema nitzschioides (Grunow) Mereschkowsky; (3) Pleurosigma distinguendum Hustedt; (4) Nitzschia sigma (Kützing) Smith; (5) Bacillaria paradoxa Gmelin; (6) Biremis circumtexta (Meister ex Hustedt) Lange-Bertalot et Witkowski; (7) Navicula sp.1; (8) Navicula erifuga Lange-Bertalot in Krammer; (9) Navicula recens (Lange-Bertalot) Lange-Bertalot in Krammer; (10) Tabularia fasciculata (Agardh) Williams et Round; (11) Nitzschia amplectens Hustedt; (12) Nitzschia brevissima Grunow; (13) Nitzschia liebethruthii Rabenhorst; (14) Fragilaria capensis Grunow; 15. Geissleria decussis (Hustedt) Lange-Bertalot et Metzeltin; (16) Staurosirella pinnata (Ehrenberg) Williams et Round; (17) Nitzschia frustulum (Kützing) Grunow in Cleve and Grunow; (18) Nitzschia laevis Hustedt; (19) Nitzschia perminuta (Grunow in Van Heurck) Peragallo. Scale bar 10 $\mu \mathbf{m}$.

ure 3(2)), Tabularia fasciculata (Figure 3(10)), Fragilaria capensis (Figure 3(14)), and Staurosirella pinnata (Figure 3(14)) were all less than $1 \%$ of the relative abundance.

A diverse naviculoid diatom like Biremis circumtexta (Figure 3(6)), Navicula sp.1 (Figure 3(7)), and Navicula recens (Figure 3(9)) were documented together with the sigmoid Pleurosigma distinguendum (Figure 3(3)), were 
found in the January and December samples.

Several biraphid diatoms with canal raphe like Nitzschia sigma (Figure 3(4)), Bacillaria paradoxa (Figure 3(5)), N. amplectens (Figure 3(11)), N. liebethruthii (Figure 3(13)), N. frustulum (Figure 3(17)), $N$. laevis (Figure 3(18)), and N. perminuta (Figure 3(19)) were potentially moving up and down the mud sediments. Identification for the following taxa; Nitzschia panduriformis (Figure 4(9)), Diploneis weissflogi (Figure 4 (11)) and an unknown Luticola sp.1 (Figure 4(12)) was confirmed with SEM analyses.

Species richness was highest during the colder months and lowest during the warmer seasons. Species richness was 34.8 on average, with the highest in January (42), and the lowest in June (26). Shannon Wiener diversity values were relatively high throughout the seasonal study, on average 2.4. Diversity values ranged from 2.7 (found during both January and December) and lowest at 1.6, during the month of June.

The highest diversity measurements were found in both January and December sampling events with values

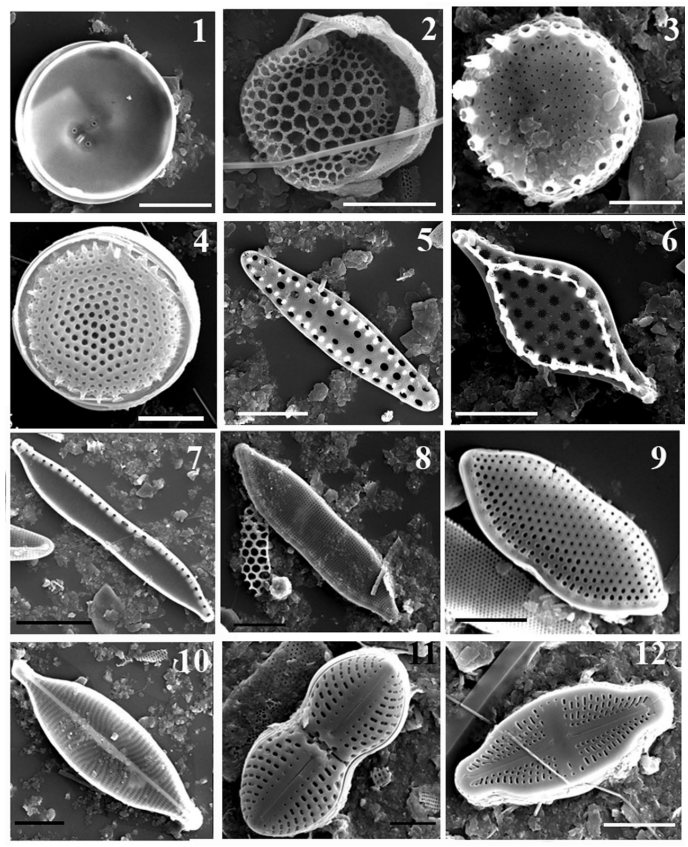

Figure 4. (1)-(12) Diatoms from the Savannah River mud samples (Scanning Electron micrographs). (1) Minidiscus chilensis Rivera; (2) Minidiscus trioculatus (Taylor) Hasle; (3) Skeletonema costatum (Greville) Cleve; (4) Thalassiosira decipiens (Grunow) Jörgensen; (5) Cymatosira belgica Grunow; (6) Cymatosira Lorenziana Grunow; (7) Nitzschia brevissima Grunow ex Van Heurck; (8) N. brevissima Grunow ex Van Heurck; (9) Nitzschia panduriformis; (10) Navicula salinarum Grunow; (11) Diploneis weissflogi (A. Schmidt) Cleve; (12) Luticola sp.1. Views, internal (1), (7), (10); external (2)-(6), (8)-(9), (11)-(12); Scale bars: $10 \mu \mathrm{m}$ for (7); $5 \mu \mathrm{m}$ for (4), (6), (8), (10), (11) and (12); $4 \mu \mathrm{m}$ for (5); $3 \mu \mathrm{m}$ for (1), (3), (9); and $2 \mu \mathrm{m}$ for (2). of 2.7. During both March and October sampling events diversity values were still high at 2.5 . Species evenness for the seasonal study followed the same trend found in diversity values. Average evenness was 0.68 , and ranged from 0.74 to 0.49 (lowest found in June). Values between January, March, October, and December remained relatively similar $(0.72,0.74,0.7$, and 0.73 respectively).

Low community indices values found within June's sample can be attributed to the large percentage of $C$. belgica (51\%) and Minidiscus sp.1 (27\%) that occurred during this time. Sorenson similarity values remained low throughout the year. Similarity was highest in October and December $(36 \%)$ and lowest between January and June samples (6\%, Table 2).

For the current study $44 \%$ of the species found in the Savannah River mud samples were classified as freshwater.

\section{Discussion}

Diversity recorded in this study is comparable only to the report by Hustedt [6]. Distribution of dominant taxa throughout the seasons remained relatively higher in the colder months than during the warmer months. Both $C$. belgica and Minidiscus sp. 1 were found occurring $>10 \%$ within all samples. In June, when the two species occurred at their highest abundances, the least amount of dominant species was observed. Centric diatoms such as P. sulcata, C. atomus and Thalassiosira sp. 1 were the most abundant plankton types. Pennate diatoms such as Nitzschia laevis (Figure 3(18)), and Navicula erifuga were the most abundant benthic species observed throughout the year. Nitzschia salinarum and N. brevissima were dominant taxa in the benthos throughout, however they were only found as dominant taxa during

Table 2. Sorenson percent similarity indices on Savannah River USGC long-term site 2198920; total SR-species richness, Shared-shared taxa between the two sites.

\begin{tabular}{cccc}
\hline Sample & Total SR & Shared & $\%$ Similar \\
\hline $1 \& 2$ & 71 & 5 & $14 \%$ \\
$1 \& 3$ & 68 & 2 & $6 \%$ \\
$1 \& 4$ & 79 & 3 & $8 \%$ \\
$1 \& 5$ & 82 & 4 & $10 \%$ \\
$2 \& 3$ & 55 & 2 & $7 \%$ \\
$2 \& 4$ & 66 & 4 & $12 \%$ \\
$2 \& 5$ & 69 & 6 & $17 \%$ \\
$3 \& 4$ & 63 & 4 & $13 \%$ \\
$3 \& 5$ & 66 & 4 & $12 \%$ \\
$4 \& 5$ & 77 & 14 & $36 \%$ \\
\hline
\end{tabular}


January.

Cymatosira belgica was observed as the dominant taxon in all samples taken and contributed more than $>20 \%$ of the total abundance in each sample taken during the seasonal study. Its highest relative abundance (51\%) was found in the warmest temperature. Cymatosira belgica is a small diatom, characterized by few morphological characters. Valves are lanceolate and slightly attenuated at the ends, which are subacute, with sparse coarse puncta, 12 in $10 \mu \mathrm{m}$, generally leaving a pseudoraphe of greater or less breadth. According to literature $C$. belgica ranges in length from $10-30 \mu \mathrm{m}$ and $3-4.5 \mu \mathrm{m}$ broad, striae up to 12 in $10 \mu \mathrm{m}$ [20]. However, Cooper [7] reports $C$. belgica ranging from $7-18 \mu \mathrm{m}$ in length. In this study, many of the C. belgica that were observed ranged from $6-14 \mu \mathrm{m}$ in length during summer months when temperatures were highest and nutrients were low suggesting that the species was reproducing rapidly in response to increased environmental factors. Further investigation of the species with higher magnification revealed that there could have been two species of Cymatosira in the Savannah River mud samples. Cymatosira belgica was reported as a dominant in mud samples from England [27], with higher abundances during low temperatures ranging from $4^{\circ} \mathrm{C}$ to $10^{\circ} \mathrm{C}$. However, on the Georgia coast highest abundances occurred in water temperatures up to $30^{\circ} \mathrm{C}$. Also it should be noted that within all our samples we have found that on average $C$. belgica length varied $6-15 \mu \mathrm{m}$ (mean $8 \pm \mathrm{SE}$ ) in length but Hofmann et al. [21] report the lengths of C. belgica to range from $10 \mu \mathrm{m}$ to $30 \mu \mathrm{m}$. The smaller specimens in the study were compared with Cymatosira minutissima Sabbe and Muylaert [28]. This is a recently described species ranging from $2.5-10 \mu \mathrm{m}$ long, $1.5-2.5 \mu \mathrm{m}$ wide, striae $18.5-24$ in $10 \mu \mathrm{m}$. Separation of the two species, C. belgica and C. minutissima largely depends on the areolae density found within the valves, which is normally a constant within species [28]. Closer examination of SEM photos allowed for a distinction to be made between the two species, however due to the relatively small size of C. minutissima under LM magnification, counts throughout the study lumped the two together as C. belgica.

Within all samples taken throughout the study Minidiscus sp. 1 occurred at a relative abundance of $>10 \%$. Under LM microscopy Minidiscus spp. are hard to detect due to the inability to see labiate and strutted processes needed for species characterization [29]. Therefore throughout counts, all Minidiscus spp. were grouped together as Minidiscus sp. 1 for relative abundances, and then separated using SEM for total species specific ecology. The genus Minidiscus Hasle, has few described taxa [30,31], and contains some of the smallest diatoms known, seldom exceeding $5 \mu \mathrm{m}$ in diameter [32], and ranging from $2-4 \mu \mathrm{m}$ in natural environments.
This diatom has complicated taxonomy, originally classified as Coscinodiscus trioculatus Taylor [33], the origination of internal position of the areolar velum and presence of fultoportulae, warranted new description falling within the family Thalassiosiraceae [30] and recognized a new genus Minidiscus [31] with the type species $M$. trioculatus.

Unlike the marginal circlet of fultoportulae, which are present within most other members of the thalassiosiroid lineage, the fultoportulae are irregularly dispersed around the center of the valve face. A single rimoportula is located near the center of the valve. A wide hyaline flange is found marginally along the valve face of the generitype, Minidiscus trioculatus (Taylor) Hasle, however this character is not found within all species. Currently, the genus Minidiscus is comprised of seven species [32,3437]. Due to their extremely small size, it is believed that the amount of diversity could be vastly underestimated [36].

After SEM images were analyzed, two species of Minidiscus were found occurring within the samples, Minidiscus chilensis (Figure 4(1)) and Minidiscus trioculatus (Figure 4(2)). In this project, richness and diversity might be underestimated due to this fact, but ecologically both species are part of the marine picoplanktonic community. They have been reported in high abundances together from Antarctica to the Alaskan coast [38] and as preferred food for upper trophic levels within the marine plankton [39]. Low temperature dependence has been reported for M. chilensis [39], however, the species is considered to be abundant and distributed worldwide [39-43]. Occurrence of the species found sessile within littoral sedimentsand associations between cell mineral-particle may allow for an adaptive advantage by affording cells enough extra mass to settle within mudflats and wait for re-suspension [38]. Minidiscus trioculatus is a cosmopolitan diatom and has wider distribution including the Gulf of Mexico [31,36, 38]. Little relationship to physicochemical parameters has been reported in the literature. In an upwelling system of central California [43] associates the Minidiscus with mineral particles.

Considering that the community similarity between our samples was never above $30 \%$ it is not surprising that overall similarity with taxa from this study and Hustedt's report was even lower. Spotted abundance information was provided by Hustedt and no information of time of collection at the Buford, N. Carolina. About $44 \%$ of the genera reported by Hustedt [6] were found in the current study, accounting for current new circumscription of the genus Navicula vs Luticula or Craticula. Hustedt's paper did not provide any information on salinity, but reclassifying the taxa with the classification from this paper resulted in less than 12 taxa being classified as freshwater and the majority is marine taxa. Species level similarity 
is less than $4 \%$ with less than $1 \%$ freshwater species in Hustedt.

In conclusion high biodiversity of the riverine epipelic community in the Savannah River delta requires consideration and preservation. There is a great potential for additional new to science discoveries of species. In addition preservation of the freshwater component of the estuarine mud community is important for stability of the sediment layer as potential food source for grazers and oxygenation of the top layer. Those properties are contributed by raphe bearing diatoms and not from centric and araphid diatoms dominating marine plankton.

\section{Acknowledgements}

Marká Smith and Robert Moseley helped with field collection. Mary Ann Tiffany helped with SEM images. This work was part of the second author's Masters graduate research at the Department of Biological and Environmental Sciences at Georgia College and State University. This work was supported by EPD Environmental protection division contract \#751-100039.

\section{REFERENCES}

[1] http://sav-harbor.com/

[2] P. V. Winger, P. J. Lasier, D. H. White and J. T. Seginak, "Effects of Contaminants in Dredge Material from the Lower Savannah River," Archives of Environmental Contamination and Toxicology, Vol. 38, No. 1, 2000, pp. 128-136. doi: $10.1007 / \mathrm{s} 002449910016$

[3] P. C. Vos and H. De Wolf, "Paleo-Environmental Research on Diatoms in Early and Middle Holocene Deposits in Central North Holland (The Netherlands)," Netherland Journal of Aquatic Ecology, Vol. 28, No. 1, 1994, pp. 97-115. doi:10.1007/BF02334250

[4] H. L. MacIntyre, R. J. Geider and D. C. Miller, "Microphytobenthos: The Ecological Role of the 'Secret Garden' of Unvegetated, Shallow-Water Marine Habitats. I. Distribution, Abundance and Primary Production," Estuaries, Vol. 19, No. 2, 1996, pp. 186-201. doi:10.2307/1352224

[5] B. B. Jorgensen and N. P. Revesbegh, "Photosynthesis and Structure of Benthic Microbial Mats: Microelectrode and SEM Studies of Four Cyanobacterial Communities," Limnology and Oceanography, Vol. 28, No. 6, 1983, pp. 1075-1093. doi:10.4319/1o.1983.28.6.1075

[6] F. Hustedt, "Marine Littoral Diatoms of Beaufort, North Carolina," Duke University Marine Station Bulletin, Vol. 6, 1995, p. 67.

[7] S. R. Cooper, "Diatoms in Sediment Cores from the Mesohaline Chesapeake Bay," USA Diatom Research, Vol. 10, No. 1, 1995, pp. 39-89. doi:10.1080/0269249X.1995.9705329

[8] E. E. Gaiser and J. Johansen, "Freshwater Diatoms from Carolina Bays and Other Isolated Wetlands on the Atlantic Coastal Plain of South Carolina, USA, with Descriptions of Seven Taxa New to Science," Diatom Research,
Vol. 15, No. 1, 2000, pp. 75-130. doi:10.1080/0269249X.2000.9705487

[9] A. K. S. K. Prasad, J. A. Nienow and R. J. Livingston, The Genus Cyclotella (Bacillariophyceae) in Choctawhatchee Bay, Florida, with Special Reference to $C$. striata and C. choctawhatcheeana sp. nov.," Phycologia, Vol. 29, No. 4, 1990, pp. 418-436. doi:10.2216/i0031-8884-29-4-418.1

[10] R. Patrick and D. M. Palavage, "The Value of Species as Indicators of Water Quality," Proceedings Academy National Science Philidelphia, Vol. 145, 1994, pp. 55-92.

[11] B. L. Sherrod, H. B. Rollins and S. K. Kennedy, "Subrecent Intertidal Diatoms from St. Catherines Island, Georgia: Taphonomic Implications," Journal of Coastal Research, Vol. 5, No. 4, 1989, pp. 665-667.

[12] APHA, "Standard Methods for Examination of Water and Wastewater," American Public Health Association, Washington DC, 1998.

[13] R. J. Stevenson and L. L. Bahls, "Chapter 6: Periphyton Protocols. Rapid Bioassessment Protocols for Use in Streams and Wadeable Rivers: Periphyton, Benthic Macroinvertebrates and Fish," 2nd Edition, US EPA Office of Water, Washington DC, 2006.

[14] C. M. Palmer and T. E. Maloney, "A New Counting Slide for Nanoplankton," American Society of Limnology and Oceanography Special Publication, Waco, 1954, p. 6.

[15] G. R. Hasle and G. A. Fryxell, "Diatoms: Cleaning and Mounting for Light and Electron Microscopy," Transactions of the American Microscopical Society, Vol. 89, No. 4, 1970, pp. 469-474. doi:10.2307/3224555

[16] K. Krammer and H. Lange-Bertalot, "Bacillariophyceae. 1. Teil: Naviculaceae," In: H. Ettl, J. Gerloff, H. Heynig and D. Mollenhauer, Eds., Süsswasserflora von Mitteleuropa, Gustav Fisher Verlag, Jena, 1986, pp. 1-876.

[17] K. Krammer and H. Lange-Bertalot, "Bacillariophyceae. 2. Teil: Bacillariaceae, Epithemiaceae, Surirellaceae," In H. Ettl, H. Gerloff, H. Heynig and D. Mollenhauer, Eds., Süsswasserflora von Mitteleuropa, Gustav Fisher Verlag, Stuttgart, 1988, pp. 1-596.

[18] K. Krammer and H. Lange-Bertalot, "Bacillariophyceae. 3. Teil: Centrales, Fragilariaceae, Eunotiaceae," In: H. Ettl, H. Gerloff, H. Heynig and D. Mollenhauer, Eds., Süsswasserflora von Mitteleuropa, Gustav Fisher Verlag, Stuttgart, 1991, pp. 1-576.

[19] K. Krammer and H. Lange-Bertalot, "Bacillariophyceae. 4. Teil: Achnanthaceae. Kritische Ergänzungen zu Navicula (Lineolatae) und Gomphonema," In: H. Ettl, G. Gärtner, J. Gerloff, H. Heynig and D. Mollenhauer, Eds., Süsswasserflora von Mitteleuropa, Gustav Fisher Verlag, Stuttgart, 1991, pp. 1-437.

[20] A. Witkowski, H. Lange-Bertalot and D. Metzeltin, "Diatom Flora of Marine Coasts, Annotated Diatom Micrographs," Diversity-Taxonomy-Identification, Vol. 1, 2000, p. 925.

[21] G. Hofmann, M. Werum und H. Lange-Bertalot, "Diatomeen im Süßwasser-Benthos von Mitteleuropa. Bestimmungsflora Kieselalgen für die ökologische Praxis. Über 700 der häufigsten Arten und ihre Ökologie. 
A.R.G.," Gantner Verlag K.G., 2011.

[22] Anonymous, "Proposals for Standardization on Diatom Terminology and Diagnoses," Nova Hedwigia, Beiheft, Vol. 53, 1975, pp. 323-354.

[23] F. E. Round, R. M. Crawford and D. G. Mann, "The Diatoms: Biology and Morphology of the Genera," Cambridge University Press, Cambridge, 1990, p. 747.

[24] E. Pielou, "An Introduction to Mathematical Ecology," John Wiley and Sons, New York, 1969.

[25] C. Shannon and W. Weaver, "The Mathematical Theory of Communication," University of Illinois, Urbana, 1949.

[26] T. Sörensen, "Method of Establishing Groups of Equal Amplitude in Plant Sociology Based on Similarity of Species Content," Kongelige Danske Videnskabernes Selskab, Vol. 4, 1948, pp. 1-34.

[27] G. J. C. Underwood, "Seasonal and Spatial Variation in Epipelic Diatom Assemblages in the Severn Estuary," Diatom Research, Vol. 9, No. 2, 1994, pp. 451-472. doi:10.1080/0269249X.1994.9705319

[28] K. Sabbe, B. Vanelslander, L. Ribeiro, A. Witkowski, K. Muylaert and W. Vvyerman, "A New Genus, Pierrecomperia gen. nov., a New Species and Two New Combinations in the Marine Diatom Family Cymatosiraceae," Life and Environment, Vol. 60, No. 3, 2010, pp. 243-256.

[29] G. R. Hasle, "Using the Inverted Microscope," In: A. Sournia, Ed., Phytoplankton Manual, UNESCO, Paris, 1978, pp. 191-196.

[30] G. R. Hasle, "Thalassiosiraceae, a New Diatom Family," Nordic Journal of Botany, Vol. 20, 1973, pp. 67-69.

[31] G. R. Hasle, "Some Marine Plankton Genera of the Diatom Family Thalassiosiraceae," Nova Hedwig, Beih, Vol. 45, 1973, pp. 1-49.

[32] C. R. Tomas, "Identifying Marine Phytoplankton," Academic Press, San Diego, 1997.

[33] J. R. Taylor, "Phytoplankton of the South Western Indian Ocean," Nova Hedwig, Beih, Vol. 12, 1967, pp. 433-476.

[34] Z. Cheng, Y. Gao and S. Liu, "Nanodiatoms from Fujian Coast," China Ocean Press, Beijing, 1993.
[35] W. Admiraal and H. Peletier, "Sulphide Tolerance of Benthic Diatoms in Relation to Their Distribution in an Estuary," British Phycological Journal, Vol. 14, No. 2, 1979, 185-196. doi:10.1080/00071617900650201

[36] J. A. Ake-Castillo, M. E. Hernandez-Becerril and M. E. M. Del Castillo and E. Bravo-Sierra, "Species of Minidiscus (Bacillariophyceae) in Mexican Pacific Ocean," Cryptogamie Algologie, Vol. 22, No. 1, 2001, pp. 101107. doi:10.1016/S0181-1568(00)01051-5

[37] I. Quiroga and M. J. Chrétiennot-Dinet, “A New Species of Minidiscus (Diatomophyceae, Thalassiosiraceae) from the Eastern English Channel, France," Botanica Marina, Vol. 47, No. 4, 2004, pp. 341-348. doi:10.1515/BOT.2004.040

[38] I. Kaczmarska, C. Lovejoy, M. Potvin and M. MacGillivary, "Morphological and Molecular Characteristics of Selected Species of Minidiscus (Bacillariophyta, Thalassiosiraceae)," European Journal of Phycology, Vol. 44, No. 4, 2009, pp. 461-475. doi:10.1080/09670260902855873

[39] J. S. Kang, S. H. Kang, D. Kim and D. Y. Kim, "Planktonic Centric Diatom Minidiscus Chilensis Dominated Sediment Trap Material in Eastern Bransfield Strait, Antarctica," Marine Ecology Progress Series, Vol. 255, 2003, pp. 93-99. doi:10.3354/meps255093

[40] P. Rivera and P. Koch, "Contribution to Diatom Flora of Chile II," In: D. G. Mann, Ed., Proceedings of the 7th International Diatom Symposium, O. Koeltz, Koenigstein, 1984, pp. 279-298.

[41] K. B. Lange, "Spatial and Seasonal Variations of Diatom Assemblages off the Argentinean Coast (South Western Atlantic)," Oceanologica Acta, Vol. 8, No. 3, 1985, pp. 361-369.

[42] C. Sancetta, "Occurrence of Thalassiosiraceae (Bacillariophyceae) in Two Fjords of British Columbia," Nova Hedwig, Beih, Vol. 100, 1990, pp. 199-215.

[43] K. R. Buck, F. P. Chavez and A. S. Davis, "Minidiscus trioculatus, a Small Diatom with a Large Presence in the Upwelling System of Central California," Nova Hedwig, Beih, Vol. 133, 2008, pp. 1-6. 